cyst from which ES cells can be derived, but the deactivated gene means that the ball lacks the ability to implant in a uterus and so develop into a baby (A. Meissner and R. Jaenisch Nature doi:10.1038/nature04257; 2005).

In the other paper, a team led by Robert Lanza of Advanced Cell Technology in Worcester, Massachusetts, plucked single cells called blastomeres from eight-cell embryos. They derived new ES cell lines from the blastomere, while the embryos went on to form apparently healthy mice (Y. Chung et al. Nature doi: 10.1038 /nature $04277 ; 2005$ ).

This method is similar to a technique used in in vitro fertilization (IVF) called preimplantation genetic diagnosis (PGD), in which a blastomere is removed from the eight-cellembryo for genetic tests before it is implanted. The work by Lanza's team
"I'm not comfortable with it. You do an engineering step to essentially destroy the embryo so you can use it." of ANT. "It is uncomfortable to me to endorse such a strategy."

Because of this, Hurlbut says that the PGD method is unlikely to get past the Dickey Amendment, which is passed by the US Congress every year and forbids federal funds being spent on experiments that endanger or destroy an embryo. And President George W. Bush's Council on Bioethics, on which Hurlbut sits, dismissed the idea earlier this year in a white paper on alternative means for deriving ES cells.

The ANT method of altering the genetic make-up of an embryo troubles some scientists, but seems more acceptable to conservative ethicists and religious figures. "I think this is an artificial concept and I'm not comfortable with it," says Trounson. "You do an engineering step to essentially destroy the embryo so that you can then use it." Because raises the possibility that fresh stem-cell lines could be derived from human embryos being used in IVF before they are transferred to the uterus.

Although the quality of the work is impressive, there is much disagreement over the ethical benefits of each strategy. Some scientists seem more convinced by the PGD method.

\section{In the balance}

"In my mind, this takes away the ethical dilemma of destroying embryos," says Alan Trounson, a reproductive biologist at Monash University in Melbourne, Australia. There is currently a moratorium on therapeutic cloning in Australia, due for review at the end of this year, and Trounson has applied to the country's major medical funding agency to do similar work with human PGD embryos.

But there is the practical disadvantage that the resulting cell lines can come only from the embryos of couples undergoing IVF, so wouldn't be genetically matched to patients. And ethicists are troubled by the question of whether the extracted blastomere itself has the potential for life. "If you grow it in certain conditions, it could divide and differentiate to have the same properties as embryos," explains Yuri Verlinsky, chief executive of the Reproductive Genetics Institute in Chicago

Although the number of successful births from PGD embryos indicates that removing a single cell early on doesn't compromise the baby, it is still possible that it might have subtle long-term consequences (see page 1075). ${ }^{\alpha}$ You are getting a live birth, but are you getting the same child you would otherwise get?" asks William Hurlbut, a consulting professor at Stanford University and a prominent advocate of this, some argue that ANT might itself fall foul of the Dickey Amendment.

George Daley of Harvard Medical School in Boston is also unconvinced, partly because the effects of the genetic modification don'tkick in until the eight-cell stage. "A normal embryo and the embryo created by this method are indistinguishable until that stage, he says.

But Hurlbut maintains that the altered embryo has no moral status. "You have the embryonic equivalent of brain death, he says. "This changes the dynamic of the political debate," agrees analystEric Cohen of the Ethics and Public Policy Center in Washington DC.

Hurlbut is doing all he can to push ANT, and has compiled a publicletter supporting it signed by scientists, ethicists and religious figures. And in August 2004, he persuaded William Levada, one of the most prominent Catholics in the United States, to write to President Bush encouraging him to consider the method. The president's bioethics council also gave the idea tentative support in its white paper.

Some observers warn against overreacting to the work. "If science gets us to the point where we don't need embryos any more that's fine, but right now policy-makers are making a huge mistake if they say 'we've got one paper and we'll make policybased on that," says Sean Tipton of the Coalition for the Advancement of Medical Research in Washington DC.

And either way, the ethical debate over what constitutes life - or the potential for life looks set to dog the field. ${ }^{\alpha}$ The challenge is to define what an embryo is," says Hurlbut. "We need to sort that out or we'll be having this argument all the way along."
STEM CELLS IN FOCUS Catch up on all of Nature's stem-cell coverageat: www.nat ure.com/news/ infoc us /stem cells.htm I

\section{Korea launches network to share cloning information}

The World Stem Cell Hub, an international network for exchanging embryonic stemcell lines and cloning technology, has been launched by the South Korean government.

Unveiled on 19 October, the hub will be headed by Woo Suk Hwang, who shot to international fame last year for successfully deriving human embryonic stem-cell lines by therapeutic cloning.

The hub's headquarters will be at Seoul National University Hospital, but it will have branches around the world that will train researchers in the technique, provide a bank of cell lines and, where local laws permit, create patient-specific lines. The first branches will be in Britain and California, but Hwang told Nature that he is also talking to researchers in Spain, Sweden and France.

Organizers hope that the first regional branch will be open by January. Each branch will need to find its own funding, but South Korea will establish a non-profit foundation to support the hub's headquarters and the travel of Korean technicians to foreign sites. Gerald Schatten, a reproductive biologist at the University of Pittsburgh, Philadelphia, who will chair the hub's international board of directors, says that the South Korean government is providing about US $\$ 50$ million.

Western scientists have cautiously welcomed the development. "I'm pleased that the Koreans have been as willing as they have to share their technology," says Arnold Kriegstein, director of the Institute for Stem Cell and Tissue Biology in San Francisco, whose staff have visited Hwang's lab.

"The Koreans are the experts - no one approaches their efficiency," adds Stephen Kennedy, a clinical researcher in reproductive medicine at the University of Oxford, UK.

But Kriegstein has ethical concerns about egg donations, and the associated issues of informed consent and record-keeping. $\mathrm{He}$ says he is also worried about the technology becoming centralized at such an early stage. Michael German, a diabetes researcher at Kriegstein's institute, agrees: “I would not like to see it become a specialized club where only a limited number of scientists have access to the technology".

Carina Dennis 